104

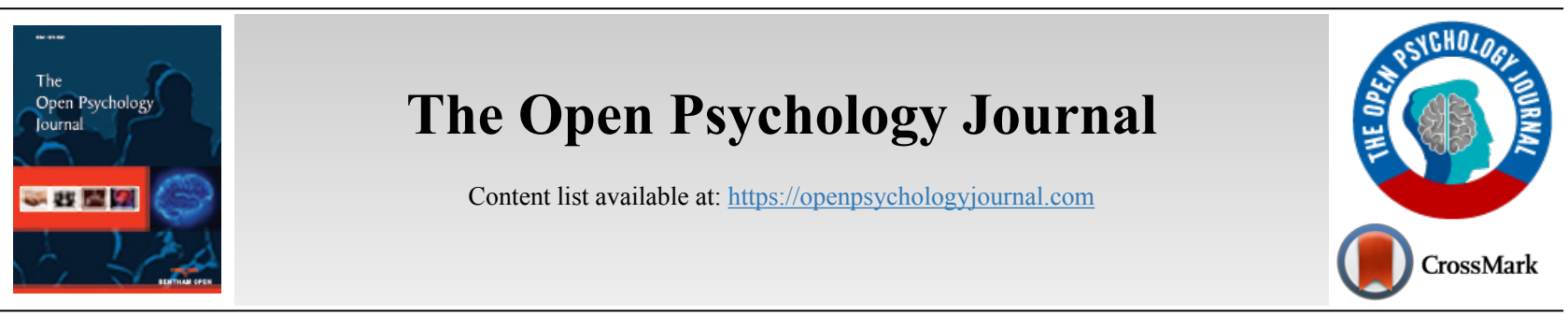

REVIEW ARTICLE

\title{
Entrepreneurial Career Probabilities of Adolescents
}

\author{
Kaethe Schneider ${ }^{1, *}$ and Vbronia Saeed ${ }^{1}$ \\ ${ }^{\prime}$ Adult Education, Friedrich-Schiller-University of Jena, Jena, Germany
}

\begin{abstract}
:
Introduction:

The extent of new enterprise creation is a key driver contributing to economic, social, individual, and cultural values. Given a relatively low rate of Total Early-stage Entrepreneurial Activity (TEA) in Germany, an understanding of the predictors of adolescent entrepreneurial career preferences is critical in developing ways to foster the interest of young people in entrepreneurship. Although the late precursors of the intention to become self-employed are largely understood, only a few studies have investigated which early individual-level factors affect the subjective probability of becoming an entrepreneur.
\end{abstract}

\section{Objective:}

The objective of the current study is to identify and statistically examine personality factors that affect the subjective probability of adolescents becoming entrepreneurs.

\section{Methods:}

Based on the German Socio-Economic Panel, we employed logistic regression to research the dependence of the variable "probability of becoming self-employed" on independent variables such as gender, locus of control (LoC), and personality traits for German adolescents aged between 16-17 years.

\section{Results:}

The study reveals a positive influence of the personality traits conscientiousness, extraversion, and LoC on the probability of being self-employed for German adolescents aged between 16-17 years. Agreeableness and neuroticism were found to have no significant effect on the subjective probability of adolescents becoming entrepreneurs, and openness was found to have no significant impact on high likelihood of being selfemployed. For adolescents, being female has a significant impact only on a medium probability to be self-employed.

\section{Conclusion:}

To the current body of personality models explaining early adolescent entrepreneurial career preferences, we contribute a model which refers to a representative sample of adolescents in German society.

Keywords: Entrepreneurial career preferences, Adolescence, Personality traits, Locus of control, Self-employment, Entrepreneurship.

\begin{tabular}{|l|l|l|l|} 
Article History & Received: October 27, 2020 & Revised: February 15, 2021 & Accepted: March 10, 2021
\end{tabular}

\section{INTRODUCTION}

The current study focuses on the subjective probability of adolescents becoming entrepreneurs. According to the OECDEUROSTAT Entrepreneurship Indicators Programme (EIP), entrepreneurs are "persons (business owners) who seek to generate value, through the creation or expansion of economic activity, by identifying and exploiting new products, processes

\footnotetext{
* Address correspondence to this author at the Adult Education, FriedrichSchiller-University of Jena, Jena, Germany; Tel: 004936419452321 ;

Fax: +49 36419 45322; E-mail: k.schneider@uni-jena.de
}

or markets" [1]. Entrepreneurship and self-employment are drivers for achieving economic growth, addressing unemployment through job creation, and creating social, individual, and cultural value. Germany, which is the focus of this study, has a $7.6 \%$ TEA rate, and in the Global Entrepreneurship Monitor, is ranked only No. 28 among 33 countries with a high income, well below Chile, Panama, Columbia, Canada, USA, UAE, Latvia, South Korea, Qatar and other countries at the top of the ranking [2]. The TEA rates in Germany amount, in contrast, to only $5.7 \%$ for women and $9.5 \%$ for men [2]. The Total Early-stage Entrepreneurial 
Activity Rate (TEA) is a key indicator of the level of new enterprise creation, which includes people in the process of starting a business (nascent entrepreneurs), and those running a new business beyond the nascent phase (three months), but before the established business phase (three and a half years).

As there is empirical evidence for the decreasing probability of entrepreneurship with respect to age [2,3], the developmental aspect of entrepreneurial competence growth $[4$, 5], and the gender gap in entrepreneurship [6], it is critical to promote the entrepreneurship of young people in Germany, especially of young women. An understanding of the predictors of adolescent entrepreneurial career preferences is needed to foster the interest of young people in entrepreneurship. Besides context-level factors, such as economic climate, there are individual-level factors (e.g., personality traits) that also affect career preferences.

Obtaining a better understanding of individual-level factors explaining entrepreneurial career preferences of young adults has been a major focus in educational and psychological research in the past decade. However, most studies that investigate how to get young adults engaged in entrepreneurship refer to late precursors of the intention to become an entrepreneur, such as student age [7 - 10]. The few studies presented to us which focused on early individual-level predictors, such as entrepreneurial personality, were related to specific samples, for example, a British representative sample [10], a sample of gifted California children born between 1903 and 1916 [11], and a sample from a single Federal State in Germany [4]. Among these studies, there was no study referring to the influence of gender, although a gender gap in entrepreneurship and personality was widely acknowledged $[12,6]$.

For the German ecosystem as a whole, possible genderrelated predictors of early entrepreneurial career intention have still not been studied. A study conducted in 2012 by Obschonka et al. [13] stated that entrepreneurship-prone personality profiles are regionally clustered in Germany. Therefore, a study of the entire German ecosystem is critical for developing nationwide gender-sensitive educational policy.

The purpose of this paper is to investigate what early personality factors affect the subjective probability of becoming an entrepreneur for German adolescents aged between 16-17 years. The background is the developmental aspect of entrepreneurship and the gender gap in entrepreneurship and personality. The objective of the study is to investigate, using data from the German SOEP, whether already at age 16-17, gender, dispositional traits, and locus of control predict the subjective probability of becoming an entrepreneur. Achieving an understanding of the key predictors is urgently needed and will be invaluable to solve a wide range of problems, e.g., developing scientifically supported educational models and gender-sensitive educational policies, unlocking adolescents' entrepreneurial potential, and addressing young people's unemployment.

\section{LITERATURE REVIEW AND HYPOTHESES}

There is increasing interest in explaining the career choice of entrepreneurship. Most studies that explain entrepreneurial career selection refer to late precursors of the intention of becoming an entrepreneur, for example, student age [7 - 10]. Studies of this type have been conducted in different countries and showed the relevance of the theory of planned behavior in explaining the intention to become self-employed, especially an entrepreneur [7 - 10]. For example, following Alharbi, Almahdi, and Mosbah [7], the intention of university students to become self-employed was positively and significantly associated with attitudes to self-employment, subjective norms, and perceived behavioral control. The attitudes of university students to self-employment, their subjective norms, and perceived behavioral control significantly interact in a positive way with their intention of becoming self-employed. Attitudes also predict preferences in a significant manner [7].

However, there has not been very much research on the early predictors of the intention to become an entrepreneur [14]. Regarding the individual-level factors of the early predictors, Schmitt-Rodermund et al. [11] found in a secondary investigation of the Terman Longitudinal Study that personality traits at age 12 and characteristics of the parental context are precursors of early entrepreneurial competencies that are predictors of entrepreneurship-prone occupational interests by the age of 13. Early entrepreneurial competencies are operationalized by roles and positions in clubs, as well as inventions. The entrepreneurship-prone occupational interests experienced at age 13 are related to the entrepreneurship-prone career goal at the average age of 27, predicting an entrepreneurship-prone occupation. The personality construct is based on the Big Five model proposed by McCrae and Costa [15]. The entrepreneurial personality predicts early entrepreneurial competencies and is characterized by higher conscientiousness, extraversion, openness, lower neuroticism, and agreeableness [11]. The secondary investigation of the Terman Longitudinal Study considered a sample of girls born in California between 1903 and 1916.

Among the studies analyzing the early precursors of entrepreneurship in a life span approach to human development, Schoon and Duckworth [10] extracted data from the 1970 British Cohort Study (BSC70). The authors examined a representative sample of 6,116 cohort members from birth to age 34 who were in full-time employment. Social skills at age 10 and entrepreneurial intention expressed at age 16 were found to be predictors of entrepreneurship at age 34. Schoon and Duckworth define entrepreneurship as the status of being self-employed and owning a business [10].

A German study was conducted in the Federal State of Thuringia (Thuringian Founder Study) in 2008 and 2009 by Obschonka et al. [5]. The study showed that recalled early entrepreneurial competence in adolescence predicted business idea generation in a sample of German scientists with an average age of 38.6. Outcomes were mediated by entrepreneurial human and social resources. Human entrepreneurial resources were assessed by focusing on prior entrepreneurial experience, and social resources were evaluated using the number of business contacts and respondent contacts with research partners in the industry. Early entrepreneurial competence, also positively correlated with entrepreneurial personality, predicted entrepreneurial human and social 
resources [5].

Utilizing data from the British Cohort Study and the Thuringia Founder Study (Germany) in a two-study analysis, Obschonka et al. [14] found for Britain as well as for Thuringia, a German Federal State, that social competencies predict entrepreneurship in young adulthood: For the British study, early social competencies positively predicted entrepreneurial status at age 34 in terms of creative class occupations, which was the focus of this study. In the study derived from the Thuringian data, early entrepreneurial social competencies referring to leadership and commercialization activities in adolescence at age 14 or 15 positively predicted the entrepreneurial intentions of German scientists. Moreover, an entrepreneurial personality profile positively predicted the intention to start a business. Obschonka et al. [14] emphasized that after controlling family background and personality (British study: locus of control, self-esteem, and academic attainment; Thuringian study: entrepreneurial personality profile), in both studies, social competencies remained a significant predictor, indicating that the relationship between social competencies and entrepreneurship cannot be fully explained by these variables [14].

With regard to the gender gap in self-employment, there is empirical evidence that personality traits [12] and self-efficacy [16] vary depending on gender. Both variables are said to interact with entrepreneurship [6]. Consistent with these results is the finding that across the US, Germany, UK, and Australia, males score higher on the entrepreneurship-prone personality profile, which predicts self-employment [6].

Given the findings of the presented studies regarding the relationship between gender and (entrepreneurial) personality, on one side, and gender and the intention to start a business, on the other, it is to be expected that in Germany, personality and gender will also predict early entrepreneurial career probability. To investigate the early role of personality and gender in differences among entrepreneurial career probabilities, we base our theoretical framework on personality theories. Hereby, we refer to the theory of McAdams and Pals [17]. They conceptualize personality "as (a) an individual's unique variation on the general evolutionary design for human nature, expressed as a developing pattern of (b) dispositional traits, (c) characteristic adaptations, and (d) self-defining life narratives, complexly and differentially situated (e) in culture and social context." [17]

In the current study, we focus on stable levels of personality, the Big Five traits, and the Locus of Control, as we want to analyze whether these personality characteristics already function as early predictors of entrepreneurial career probabilities. Within this theoretical framework of personality, we selected the Five-Factor model of dispositional traits [18] and the generalized, temporally stable, and cross-situationally working expectancies for internal versus external control of reinforcement, the Locus of Control (LoC) [19].

Dispositional traits "are generally viewed as broad dimensions of individual differences between people, accounting for inter-individual consistency and continuity in behavior, thought, and feeling across situations and over time."
[17] Referring to the fundamental personality model, the BigFive Factor Theory (FFT), dispositional traits are grouped into the five factor-analytically-derived categories of extroversion (vs. introversion), neuroticism (negative affectivity), conscientiousness, agreeableness, and openness to experience [17]. McCrae and Costa (1999) assume in their five-factor theory (FFT) that dispositional personality traits are determined by biological factors [15]. Characteristic adaptations are "motivational, social cognitive, and developmental variables that are contextualized in time, situations, and social roles." [11] They are an individual's characteristic adaptations as they result from traits and at the same time from "ongoing interactions with the environment" [20].

Following the Five-Factor Model of Personality, dispositional traits represent coherent and constant structures of a person's feelings, thoughts, and forms of behavior [18]. To specify these traits, a person with high openness to experience sees herself as having a lively imagination, being original and creative, and appreciating artistic and aesthetic experiences [21]. Persons with high conscientiousness develop a self-image of being highly motivated, success-oriented, thorough in their work, and completing their tasks effectively and efficiently [21]. Persons with high values for extroversion describe themselves as communicative, talkative, open, and outgoing. Individuals with high values for neuroticism regard themselves as nervous, often worried, and having difficulties in dealing with stress [21]. A person who describes herself as agreeable is considerate and friendly, willing to forgive, and kind to others [21].

Rotter [19] introduced the concept of generalized expectancies for internal versus external control, conceptualized as the locus of control. The locus of control is regarded as internal in the case of a person who believes she can control her own life and as external in the case where a person sees her life as controlled by outside factors she cannot influence. Following Rotter [19], we regard the LoC as relatively stable domain-overarching control orientations, in contrast to domain-specific contextualized ones. Comparable to Obschonka and Stuetzer [20], we regard generalized expectancies as "characteristic adaptations."

From the presented studies, we know that the entrepreneurial personality is constituted by traits characterized by low agreeableness and neuroticism, high extroversion, openness, and conscientiousness, and the entrepreneurial locus of control as a characteristic adaptation [20]. Since dispositional traits are genetically anchored, and the locus of control is shaped on the basis of early childhood experiences of contingencies of rewards and reinforcements of prior behaviors [19], the entrepreneurial personality develops already early with stable shares [22, 23].

We assume that the relatively stable factor of a general locus of control "as a generalized expectancy relating behavior to reinforcement in a wide variety of learning situations" [24] contributes to the subjectively assessed probability of becoming self-employed. As a business owner seeks to generate value through the creation or expansion of economic activity, meaning that the person seeks to determine the reinforcements "that occur relative to his behavior" [24], we 
regard internal control beliefs, as well as marked aim and planning orientation, as critical individual level success factors.

Hypothesis 1: Higher levels of conscientiousness, extraversion, and openness and lower levels of neuroticism and agreeableness are associated with higher entrepreneurial career probabilities at age 16-17.

Hypothesis 2: The internal locus of control predicts entrepreneurial career probability at age 16-17.

Hypothesis 3: Being female is negatively associated with early entrepreneurial career intention at age 16-17.

Referring to the process of occupational choice, it is important for us to understand this choice as a developmental process. According to Ginzberg et al. [25], choice occurs over the following three periods: The period of fantasy choice (ages 7-11) is marked by inadequate realism in professional wish conceptions, which is hardly characterized by reflection on the occupational requirements. In the period of trial or respectively attempted choice (ages 11-17), the youth brings interests, abilities, and values into the professional choice process. After the 17 th year of life, a realistic career choice is made.

As we learned that becoming an entrepreneur is associated with entrepreneurial intentions expressed at age 16 [11], and a realistic choice of profession typically occurs after the 17 th year of life [25], we chose the age group of 16 to 17-year-olds in our sample, to be able to predict at the earliest possible age the realistically estimated subjective probability of becoming self-employed.

Based on the presented empirical studies and our theoretical framework, we hypothesize that at age 16-17 the subjective probability of becoming self-employed can be positively associated with extroversion, openness and conscientiousness, and negatively associated with agreeableness and neuroticism (Fig. 1). Regarding the locus of control, we hypothesize that a high internal locus of control will positively impact the subjective probability of becoming self-employed, and gender is negatively associated with the subjective probability of becoming self-employed (Fig. 1).

\section{METHODS}

In the context of national and international statistics, there are several collections of statistics, such as, e.g., the Global Entrepreneurship Monitor (GEM), the National Educational Panel Study (NEPS), and the Socio-Economic Panel (Sozioökonomisches Panel: SOEP), which continuously provide statistical data on the subject of entrepreneurship. We focus our study on Germany, and therefore we used data collected in Germany by the Socio-Economic Panel (SOEP), a nationally representative annual follow-up study of private households by the German Institute for Economic Research (Deutsches Institut für Wirtschaftsforschung (DIW). We based our study on the most recent year, 2018. We chose the SOEP dataset as it contains information on youth, the age group between 16 and 17-years old, their individual characteristics, such as dispositional personality traits and locus of control (LoC) [26]. Moreover, the survey questions included assessments of the subjective probability of becoming self-employed [26]. This project used multivariate estimation to examine in an exploratory way the effects of individual characteristics on early entrepreneurial career probabilities.

\subsection{Measurement of Variables}

We included three variables for the sample members' characteristics in our logit estimates, locus of control, personality traits and gender as our independent variables, and probability of being self-employed as our dependent variable.

Probability to be self-employed. The probability of being self-employed is divided into 11 categories, ranging from $0 \%$ to be self-employed to $100 \%$ to be self-employed.

Personality traits. Personality traits were measured with the well-validated German-Big Five questionnaire based on the Ten-Item Personality Inventory (TIPI) [27] and the established.

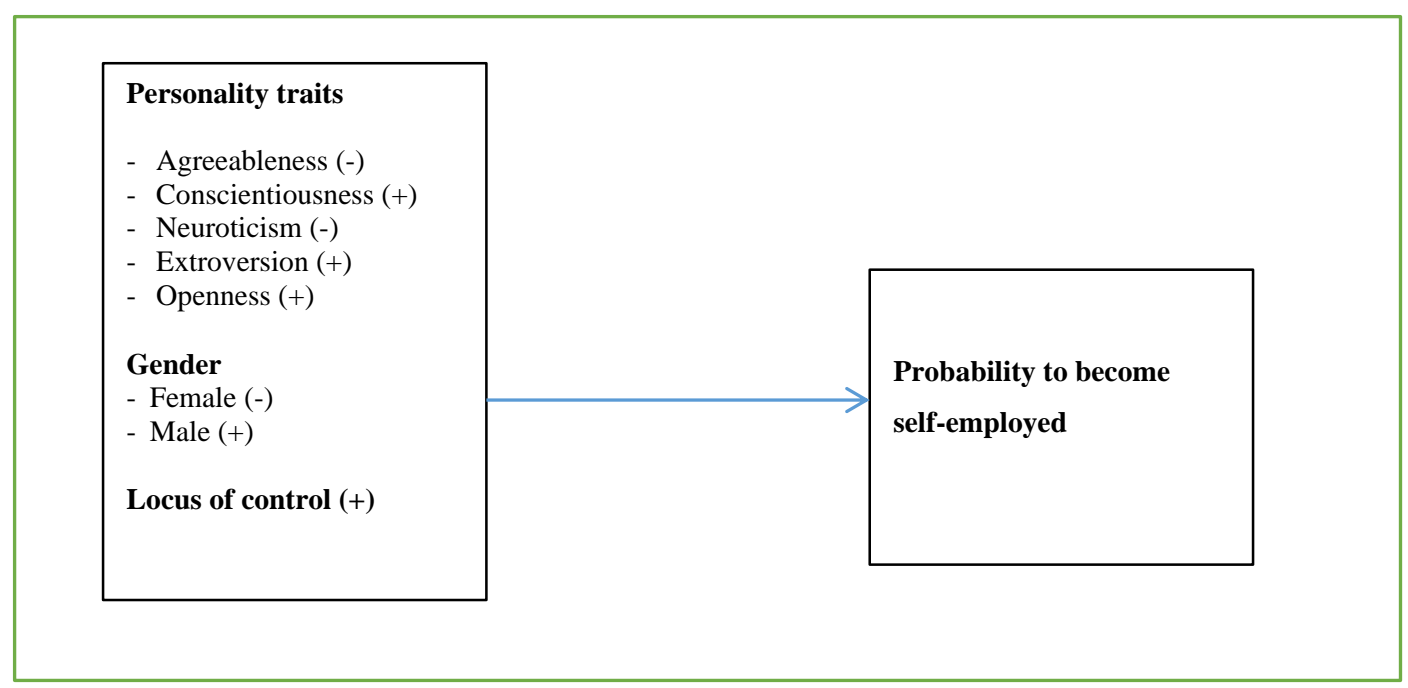

Fig. (1). Conceptual model (Expected directions of relationships are presented in parentheses). 
"Big Five" Inventory (BFI-25) [28]. The participants in the 2018 wave of GSOEP were asked to fill out the Big Five scale based on the Five-Factor Model. Respondents rated their personality on 16 items with four items for the trait of openness (e.g., "I am someone who values artistic, aesthetic experiences"; $\alpha=.59$ ) and three items for each of the following four traits on a 7-point Likert scale ranging from $1=$ not true for me at all to 7 = completely true for me): agreeableness (e.g., "I am forgiving"; $\alpha=.47$ ); conscientiousness (e.g., "I am effective and efficient in completing tasks"; $\alpha=.66$ ); extraversion (e.g., "I am communicative and talkative"; $\alpha=$ .74); and neuroticism (e.g., "I am nervous"; $\alpha=.54$ ) [21]. The Big-Five scale has demonstrated both satisfactory reliability in terms of internal consistency and test-retest stability [21]: The test-retest correlations were .64 for the 3 -item version of openness $(N=325)$ and .66 for the 4 -item version $(N=167)$; .53 for conscientiousness; .64 for extraversion; .57 for agreeableness; and .62 for neuroticism [29]. Further information on the scale and evidence of reliability and validity in the GSOEP data can be found in studies by Gerlitz and Schupp [29] and Lang et al. [30].

Locus of Control. Locus of Control was evaluated using the Locus of Control Scale developed by Helmut Nolte [31]. The scale includes four dimensions in the original version [19]: 1. Internal locus of control (3 Items), 2. External locus of control (E, 5 Items), 3. Attitudes about fairness or justice (1 Item) and 4. Individual $v s$. collective orientation (1 Item). Although the original version contains 10 items, a set of 7 items can be aggregated into a scale with acceptable internal consistency [21]. The scale $(\alpha=.68)$ is scored in such a way that higher values indicate an internal locus of control. Respondents rated their locus of control on seven items (e.g., "How my life goes depends on me") on a 7-point Likert scale ranging from $1=$ absolutely to $7=$ not at all. Test-retest correlations for the scale-relevant items $1,2,3,5,7,8$, and 10 were $.45, .47, .45, .33, .43, .26, .21$, respectively; scale scores correlated .56 [21]. Further information on the scale and evidence on the reliability and validity of the GSOEP data can be found in the study by Richter et al. [21].

\subsection{Sample Construction}

The sample consisted of youth between 16-17 years of age in 2018. To predict the probability of becoming an entrepreneur, we used the probability of becoming selfemployed as our dependent variable. The probability of becoming self-employed ranged from $0 \%$ to $100 \%$. Our dependent variable is a categorical variable that ranges from 0 to 100.0 refers to a $0 \%$ chance to be self-employed, whereas 100 refers to a $100 \%$ probability to be self-employed.

For predicting the probability of being self-employed, we used the variables regarding the locus of control and variables about personal characteristics and gender. The sample descriptive statistics for the variables of interest are shown in Table 1. To measure the locus of control, we aggregated the scaled variables, as shown in Table $\mathbf{1}$, in the main component, while we measured personality traits according to the entrepreneurship-prone personality profile developed by Schmitt-Rodermund [22, 23]. To compute the entrepreneurship-prone personality profile, we calculated the difference between the individual's Big Five profile and the reference profile [13]. Matching the codes to the defining outer limits of the single Big Five traits within an entrepreneurshipprone personality, we first recoded our scale from 0 to 6 instead of 1 to 7 [13]. After recoding Big Five scores, the entrepreneurial reference type was defined as the highest possible score (4) on extraversion, conscientiousness, and openness, and the lowest possible score (0) on agreeableness and neuroticism [13].

We then calculated the "goodness-of-fit" of each person's Big Five profile with respect to the entrepreneurship-prone Big Five profile by squaring the differences between the reference values and the personal values on each of the five scales. These squared differences were summed for each person, and the algebraic sign of this sum was reversed [13].

The lower the value for agreeableness and neuroticism $(\mathrm{M}=-56.03$ and $-41.01, \mathrm{SD}=18.24$ and 18.59 consecutively) and the higher the value for openness, extraversion, and conscientiousness $(\mathrm{M}=-71.93,-52.18$ and $-52.67, \mathrm{SD}=32.99$, 19.99 and 17.85 consecutively), the better the fit between the person's big five personality profile and the reference value (Table 1).

In order to measure the reliability and consistency of our independent variables, we applied the Cronbach alpha measure. Our Cronbach's value of 0.62 indicates an acceptable level of reliability, as mentioned in a previous study [32,33].

However, we found a negligible but positive significant relationship between the probability to be self-employed and openness. While most independent variables show positive significant but weak relationships with each other, gender shows only a significant but negative negligible relationship with agreeableness (significance level at 0.05) (Table 2).

Table 1. Descriptive statistics for metric variables of entrepreneurship-prone Big Five personality traits, LoC, and gender.

\begin{tabular}{|c|c|c|c|c|c|}
\hline Variables & Obs. & Mean & Std. Dev. & Min. & Max. \\
\hline Probability to be self-employed & 455 & 36.42 & 29.26 & 0 & 100 \\
\hline Agreeableness & 568 & -56.03 & 18.24 & -108 & -9 \\
\hline Openness & 568 & -71.93 & 32.99 & -144 & -1 \\
\hline Neuroticism & 568 & -41.01 & 18.59 & -108 & -2 \\
\hline Conscientiousness & 568 & -52.67 & 17.85 & -108 & -5 \\
\hline Extraversion & 568 & -52.18 & 19.99 & -108 & 0 \\
\hline Gender & 568 & 1.47 & 0.50 & 1 & 2 \\
\hline Locus of control & 443 & 0 & 1.48 & -3.39 & 4.15 \\
\hline
\end{tabular}


Table 2. Correlation table.

\begin{tabular}{|l|c|c|c|c|c|c|c|c|c|}
\hline- & - & $\mathbf{1}$ & $\mathbf{2}$ & $\mathbf{3}$ & $\mathbf{4}$ & $\mathbf{5}$ & $\mathbf{6}$ & $\mathbf{7}$ & $\mathbf{8}$ \\
\hline 1 & LoC & 1 & & & & & & & \\
\hline 2 & Extraversion & $0.12^{*}$ & 1 & & & & & & \\
\hline 3 & Conscientiousness & $0.15^{*}$ & $0.34^{*}$ & 1 & & & & & \\
\hline 4 & Openness & $0.11^{*}$ & $0.37^{*}$ & $0.27^{*}$ & 1 & & & & \\
\hline 5 & Neuroticism & $-0.12^{*}$ & $0.22^{*}$ & $0.30^{*}$ & $0.17^{*}$ & 1 & & & \\
\hline 6 & Agreeableness & $0.18^{*}$ & $0.39^{*}$ & $0.28^{*}$ & $0.32^{*}$ & $0.36^{*}$ & 1 & & \\
\hline 7 & Gender & -0.004 & -0.10 & -0.05 & -0.10 & -0.10 & $-0.10^{*}$ & 1 & \\
\hline 8 & Probability of self-employment & 0.02 & -0.04 & -0.10 & $-0.15^{*}$ & -0.03 & -0.05 & -0.10 & 1 \\
\hline
\end{tabular}

Source: SOEP Data [27], own calculations.

\section{ANALYSIS}

We employed a multinomial logistic model to study the impact of the locus of control, personality characteristics, and gender on the probability of being self-employed in Germany in 2018 (Table 3). The multinomial logistic regression shows the impact of our independent variables on each category of the dependent variable; that is, each categorical percentage to be self-employed. The ten categories of our dependent variables are represented by each model, such that model 1 represents the result of $10 \%$ of being self-employed, model 2 represents $20 \%$, and so on.

\section{EMPIRICAL RESULTS}

Extraversion has a significant impact on the self-assessed probability of being self-employed at $10 \%$ - and $20 \%$-ages levels. Thus, extraversion significantly predicts a low selfassessed chance to become an entrepreneur. The one-point increase in extraversion resulted in 0.31 and 0.24 respective increase in the multinomial log-odds for youth who were assigned $10 \%$ and $20 \%$ likelihood of becoming self-employed relative to $0 \%$ of becoming self-employed, while holding other variables in the model constant (the estimated multinomial logodds are significant at the $5 \%$ significance level). Conscientiousness was found to have a significant effect on $40 \%$ of the probability of being self-employed. This positive effect was reflected in the increase in the multinomial log-odds of $40 \%$ of being self-employed by 0.03 for a point increase in conscientiousness while holding other variables in the model constant (the estimated multinomial log-odds are significant at the $5 \%$ significance level).

While agreeableness and neuroticism showed no significant effect on the probability of being self-employed, openness showed a significant negative effect on the $80 \%$ and $90 \%$ relative to $0 \%$ of the probability of being self-employed. Thus, openness is negatively associated with a highly probable assessment of youth to become self-employed. For a point increase in openness resulted in a 0.02 decrease in the multinomial logit odds for assigned $80 \%$ and $90 \%$ probability to become self-employed relative to $0 \%$ to be self-employed, while holding other variables in the model constant (the estimated multinomial log-odds are significant at the $5 \%$ significance level).

For the locus of control, we found a significant positive effect on the self-assessed probability to become selfemployed. However, this effect is only significant when the probability of being self-employed as self-assessed by youth is $90 \%$.

If youth increased their LoC by one point, the multinomial log-odds for $90 \%$ probability of being self-employed, a probability that can be regarded as most likely to happen, relative to $0 \%$ of being self-employed, would be expected to increase by 0.50 , while holding other variables in the model constant (the estimated multinomial log-odds are significant at the $5 \%$ significance level).

The impact of gender was only significant on a medium level $(40 \%)$ probability of being self-employed. The multinomial logit estimate for females compared to males was 0.93 higher for $40 \%$ relative to $0 \%$ of the probability of being self-employed, given that other predictors were kept constant (the estimated multinomial log-odds are significant at the 5\% significance level).

In terms of our hypotheses, we can state for our first hypothesis that, on the one hand, conscientiousness and extraversion show positive significant multinomial log-odds with the probability of being self-employed (with $40 \%$ and $10 \%$ and $20 \%$ of the probability to be self-employed consecutively), while openness shows negative significant multinomial log-odds with the probability of being selfemployed (with $90 \%, 80 \%$ and $20 \%$ probability of being selfemployed consecutively). On the other hand, agreeableness and neuroticism show insignificant and inconsistent negative signs among all probabilities to be self-employed. Therefore, our first hypothesis is partially supported. Since the locus of control shows positive and significant results with the multinomial log-odds to be self-employed (with $90 \%$ of the probability to be self-employed), our second hypothesis is supported. However, our third hypothesis is not supported, as being a female shows positive significant multinomial log-odds to be self-employed (with $40 \%$ of the probability of being selfemployed).

Since our model has a multilevel categorical dependent variable, we employed the Hosmer-Lemeshow Test (HLT) to evaluate the goodness of fit for multinomial logistic regression [34]. According to the P-value (0.844), we did not reject the null hypothesis (Table 4). This shows that the fitted model is correct and fits the data well. 
Table 3. Predictors of the subjectively estimated probability of becoming self-employed: multinomial logistic model.

\begin{tabular}{|c|c|c|c|c|c|c|c|c|c|c|}
\hline Variables & \multicolumn{10}{|c|}{ Multinomial log odds } \\
\hline \multirow{2}{*}{$\begin{array}{l}0 \% \text { to be self- } \\
\text { employed }\end{array}$} & \multicolumn{10}{|c|}{ Base outcome } \\
\hline & \begin{tabular}{|l|} 
Model 1 \\
{$[10 \%$ to be } \\
self-employed $]$
\end{tabular} & \begin{tabular}{|l} 
Model 2 \\
{$[20 \%$ to be } \\
self-employed]
\end{tabular} & \begin{tabular}{|l|} 
Model 3 \\
{$[30 \%$ to be } \\
self-employed]
\end{tabular} & \begin{tabular}{|l|} 
Model 4 \\
{$[40 \%$ to be } \\
self-employed $]$
\end{tabular} & $\begin{array}{l}\text { Model } 5 \\
{[50 \% \text { to be }} \\
\text { self-employed }]\end{array}$ & \begin{tabular}{|l} 
Model 6 \\
{$[60 \%$ to be } \\
self-employed $]$
\end{tabular} & \begin{tabular}{|l|} 
Model 7 \\
{$[70 \%$ to be } \\
self-employed]
\end{tabular} & \begin{tabular}{|l|} 
Model 8 \\
{$[80 \%$ to be } \\
self-employed $]$
\end{tabular} & \begin{tabular}{|l|} 
Model 9 \\
{$[90 \%$ to be } \\
self-employed $]$
\end{tabular} & $\begin{array}{l}\text { Model } 10 \\
{[100 \% \text { to be }} \\
\text { self-employed }]\end{array}$ \\
\hline Locus of control & -0.01 & -0.09 & 0.09 & 0.19 & 0.08 & -0.16 & 0.27 & -0.10 & $0.50 *$ & -0.33 \\
\hline Extraversion & $0.03 * *$ & $0.02 *$ & 0.020 & 0.02 & 0.02 & 0.02 & 0.02 & 0.023 & 0.01 & -0.002 \\
\hline Conscientiousness & -0.01 & 0.005 & 0.016 & $0.03 *$ & -0.004 & 0.01 & -0.01 & 0.01 & -0.02 & -0.03 \\
\hline Openness & -0.002 & -0.001 & 0.006 & -0.01 & -0.008 & -0.02 & -0.01 & $-0.02 *$ & $-0.02 *$ & -0.001 \\
\hline Neuroticism & -0.02 & 0.011 & -0.01 & 0.002 & 0.003 & 0.004 & 0.008 & 0.01 & 0.03 & -0.03 \\
\hline Agreeableness & -0.005 & -0.01 & -0.01 & -0.005 & 0.003 & -0.013 & -0.008 & -0.02 & 0.004 & -0.015 \\
\hline Female & -0.14 & -0.20 & 0.13 & $0.93 *$ & -0.11 & -0.62 & -0.47 & 0.47 & 0.26 & -0.21 \\
\hline Constant & -1.03 & -0.09 & 0.29 & 0.02 & 0.21 & -1.8 & -1.28 & -1.69 & $-2.8^{*}$ & $-6.2 * * *$ \\
\hline$N$ & \multicolumn{10}{|l|}{432} \\
\hline Pseudo R2 & \multicolumn{10}{|l|}{0,0508} \\
\hline Log likelihood & \multicolumn{10}{|l|}{-918.41354} \\
\hline $\mathrm{LR} \mathrm{Chi}^{2}$ & \multicolumn{10}{|l|}{98.26} \\
\hline Prob $>$ chi $^{2}$ & \multicolumn{10}{|l|}{0.0146} \\
\hline
\end{tabular}

Table 4. Goodness-of-fit test for a multinomial logistic regression model: Hosmer-Lemeshow test (HLT).

\begin{tabular}{|c|c|}
\hline Dependent variables & Probability of being self-employed \\
\hline Number of observations & 432 \\
\hline Base outcome value & 0 \\
\hline Number of outcome values & 11 \\
\hline Number of groups & 10 \\
\hline Chi-squared statistic & 67.269 \\
\hline Degrees of freedom & 80 \\
\hline Prob $>$ chi-squared & 0.844 \\
\hline
\end{tabular}

Source: SOEP Data [27], own calculations.

\section{DISCUSSION}

The purpose of this paper was to study early individuallevel factors that affect the subjective probability of becoming an entrepreneur for German adolescents aged between 16-17 years. To predict the probability of becoming self-employed, we used a principal component of seven variables that implies the locus of control, a measurement of the entrepreneurshipprone personality profile to indicate the big five personality characteristics and gender.

The multinomial logit model reveals a significant positive impact of the locus of control on $90 \%$ of the probability of being self-employed and a significant positive impact of being female and exhibiting conscientiousness on $40 \%$ of the probability of being self-employed. Thus, being a female can only have a significant impact on $40 \%$ of the probability of being self-employed. Additionally, showing extraversion has a significant positive impact on a relatively lower level of the self-assessed probability ( $10 \%$ and $20 \%$ of the probability) of being self-employed. These results confirm our hypothesis regarding the positive influence of these personality traits and LoC on the probability of being self-employed.

Contrary to our hypothesis, openness was found to have no significant effect or a significant negative effect on $80 \%$ and $90 \%$ of the probability of being self-employed. Similarly, agreeableness and neuroticism were found to have no significant effect on any of the categorical percentages to be self-employed. Thus, our results provided more support for hypotheses related to the locus of control than those related to personality traits and gender. Antonic et al. [35] found similar results regarding the non-significance effect of neuroticism, arguing that neuroticism and conscientiousness were not very relevant for entrepreneurs, as being systematic and efficient does not necessarily lead to being an entrepreneur. Hachana et al. [36] also found that agreeableness does not affect entrepreneurial intention, as successful entrepreneurs are often introverted and disagreeable. They explained that entrepreneurs sometimes benefit from being manipulative and suspicious in the light of the rapidly changing entrepreneurial environment. Additionally, the negative effect of openness on the probability of being self-employed is due to the fact that we studied potential entrepreneurs and not practicing entrepreneurs, as Kerr et al. [37] found that potential entrepreneurs are less open than practicing entrepreneurs.

Therefore, the study has three theoretical implications: Firstly, assuming that, following Schmitt-Rodermund [11], the entrepreneurial personality is characterized by higher conscientiousness, extraversion, openness, lower neuroticism, and agreeableness. We need a deeper understanding of why, unexpectedly, agreeableness and neuroticism were found to have no significant effect on any of the categorical percentage of proneness to be self-employed, and openness was found to 
have no significant effect or a significant negative effect on $80 \%$ and $90 \%$ probability of being self-employed. The differences between the predicting personality factors of students or entrepreneurs and those of adolescents might be due to (1) the quality of the occupational assessment in terms of being realistic at the age of 16, (2) the question itself of assessing the probability of becoming self-employed as a way of anticipating career changes ("How likely is it that you will experience the following career changes?"), and (3) the development of personality characteristics during the transition from adolescence to adulthood, which is characterized by significant life changes. Following Kerr, Kerr, and Xu [37], we therefore still need to consider that it is an open question whether "individuals with a given set of personality traits selected into entrepreneurship, or whether individuals developed the traits endogenously after becoming entrepreneurs." Future research is needed to investigate the stability and dynamics of occupational assessment, as well as the predictors from a longitudinal perspective.

Secondly, in line with the results of the secondary investigation of the Terman Longitudinal Study conducted by Schmitt-Rodermund et al. [11], it is of particular interest to analyze the impact of the personality traits which not only empirically [11] but also theoretically result in context-related characteristic adaptations; here, entrepreneurial competencies. These are thought to affect entrepreneurship-prone occupational interests.

Thirdly, against the background of the Big Five model proposed by McCrae and Costa [15], which modeled broad individual differences into factor-analytically-derived categories, a functional analytic perspective, proposed by Julius Kuhl's Personality-System-Theory [38], might enrich the theoretical foundation in entrepreneurship research by taking a more dynamic and complex perspective on the personality, as "the entrepreneurial intention" is a "developmental outcome" [5].

Regarding the practical implications of the current study, the relatively stable locus of control, with its early impact on a highly probable entrepreneurial career selection expressed at the age between 16 and 17 , requires pedagogical stimulation already during childhood.

\section{CONCLUSION}

To the best of our knowledge, this research is the first study of the entire German ecosystem where personality traits of adolescents were investigated for their influence on the subjective probability of becoming an entrepreneur. With our study, we were able to contribute to the present body of personality models explaining early adolescent entrepreneurial career preferences with a model that refers to a representative sample of adolescents in German society.

\section{LIMITATIONS}

However, we must interpret the findings in light of several difficulties because the current study was subject to data limitations: According to the developmental perspective of occupational choice, a choice can be understood as a long-term process in which self-concept and occupational preferences develop interactively. To gain a deeper understanding of the developmental process of becoming an entrepreneur, research would benefit from a methodological approach that is sensitive to these long-term changes. The most recent version of the SOEP-Core data contains no data on personality factors and occupational assessment for adolescents younger than 16 and older than 17 years.

Applying a theoretical developmental perspective would require a longitudinal methodological approach. We have had difficulty creating a panel sample, as we cannot follow the same individuals across the years to investigate the stability of personality factors, locus of control, and the assessed probability of becoming self-employed and long-term effects. Results may be biased because of younger sample members who are still unable to make realistic choices.

\section{CONSENT FOR PUBLICATION}

Not applicable.

\section{FUNDING}

None.

\section{CONFLICT OF INTEREST}

The authors declare no conflict of interest, financial or otherwise.

\section{ACKNOWLEDGEMENTS}

Declared none.

\section{REFERENCES}

[1] Ahmad N, Seymour R. Defining Entrepreneurial Activity: Definitions Supporting Frameworks for Data Collection. OECD Statistics Working Papers 2008.

[2] Sternberg R, Gorynia-Pfeffer N, Wallisch M, Baharian A, Stolz L, von Bloh J. Global Entrepreneurship Monitor Unternehmensgründungen im weltweiten Vergleich Länderbericht Deutschland 2019/2020. RKW Kompetenzzentrum 2020.

[3] Gómez-Araujo E, Bayon MC. Socio-cultural factors and youth entrepreneurship in rural regions. RBGN 2017; 19(64): 200-18. [http://dx.doi.org/10.7819/rbgn.v0i0.2695]

[4] Obschonka M, Silbereisen RK, Schmitt-Rodermund E. Explaining entrepreneurial behavior: Dispositional personality traits, growth of personal entrepreneurial resources, and business idea generation. Career Dev Q 2012; 60: 178-90.

[http://dx.doi.org/10.1002/j.2161-0045.2012.00015.x]

[5] Obschonka M, Silbereisen RK, Schmitt-Rodermund E. Entrepreneurial intention as developmental outcome. J Vocat Behav 2010; 77: 63-72. [http://dx.doi.org/10.1016/j.jvb.2010.02.008]

[6] Obschonka M, Schmitt-Rodermund E, Terracciano A. Personality and the gender gap in self-employment: A multi-nation study. PLoS One 2014; 9(8)e103805

[http://dx.doi.org/10.1371/journal.pone.0103805] [PMID: 25089706]

[7] Alharbi J, Almahdi H, Mosbah A. The impact of entrepreneurship education programs (eeps) on the entrepreneurial attitudes among higher education students. Int J. Man. Eco Soc Sci 2018; 7(3): 245-71. [http://dx.doi.org/10.32327/IJMESS.7.3.2018.16]

[8] Ferri L, Ginesti G, Spano R, Zampella A. Exploring factors motivating entrepreneurial intentions: The case of Italian university students. Int J Train Dev 2019; 23(3): 202-20. [http://dx.doi.org/10.1111/ijtd.12158]

[9] Whidya Utami C. Attitude, subjective norms, perceived behavior, entrepreneurship education and self-efficacy toward entrepreneurial intention university student in indonesia. Euro Res Stud J 2017; 0(2A): 475-95.

[10] Schoon I, Duckworth K. Who becomes an entrepreneur? Early life experiences as predictors of entrepreneurship. Dev Psychol 2012; 
48(6): 1719-26.

[http://dx.doi.org/10.1037/a0029168] [PMID: 22746220]

[11] Schmitt-Rodermund E, Schröder E, Obschonka M. Studying entrepreneurial occupations in the Terman women. Int J Psychol 2019; 54(2): 164-73

[http://dx.doi.org/10.1002/ijop.12450] [PMID: 28714080]

[12] Schmitt DP, Realo A, Voracek M, Allik J. Why can't a man be more like a woman? Sex differences in Big Five personality traits across 55 cultures. J Pers Soc Psychol 2008; 94(1): 168-82.

[http://dx.doi.org/10.1037/0022-3514.94.1.168] [PMID: 18179326]

[13] Obschonka M, Schmitt-Rodermund E, Silbereisen RK, Gosling SD, Potter J. The regional distribution and correlates of an entrepreneurship-prone personality profile in the United States, Germany, and the United Kingdom: A socioecological perspective. J Pers Soc Psychol 2013; 105(1): 104-22. [http://dx.doi.org/10.1037/a0032275] [PMID: 23586410]

[14] Obschonka M, Duckworth K, Silbereisen RK, Schoon I. Social competencies in childhood and adolescence and entrepreneurship in young adulthood: A two-study analysis. Int J Dev Sci 2012; 6(3-4): 137-50.

[http://dx.doi.org/10.3233/DEV-2012-12108]

[15] McCrae RR, Costa PT. A five-factor theory of personality.Handbook of personality Theory and research. New York, NY: Guilford Press 1999; pp. 139-53.

[16] Kickul JR, Wilson F, Barbosa SD, Marlino D, Griffiths MD. An analysis of the role of gender and self-efficacy in developing female entrepreneurial interest and behavior. J Dev Entrep 2009; 14: 105-19. [http://dx.doi.org/10.1142/S1084946709001247]

[17] McAdams DP, Pals JL. A new Big Five: Fundamental principles for an integrative science of personality. Am Psychol 2006; 61(3): 204-17. [http://dx.doi.org/10.1037/0003-066X.61.3.204] [PMID: 16594837]

[18] Costa PT, McCrae RR. The NEO personality inventory manual. Psychological Assessment Resources 1985.

[19] Rotter JB. Generalized expectancies for internal versus external control of reinforcement. Psychol Monogr 1966; 80(1): 1-28. [http://dx.doi.org/10.1037/h0092976] [PMID: 5340840]

[20] Obschonka M, Stuetzer M. Integrating psychological approaches to entrepreneurship: The Entrepreneurial Personality System (EPS). Small Bus Econ 2017; 49(1): 203-31.

[http://dx.doi.org/10.1007/s11187-016-9821-y]

[21] Richter D, Rohrer J, Metzing M, Nestler W, Weinhardt M, Schupp J. SOEP Scales Manual (updated for SOEP-Core v321). SOEP Survey Papers. Series C. DIW Berlin/SOEP 2017.

[22] Schmitt-Rodermund E. The long way to entrepreneurship. Personality, parenting, early interests and competencies for entrepreneurial activity among the "termites".Approaches to positive youth development. Thousand Oaks, CA: Sage 2007; pp. 205-24.

[http://dx.doi.org/10.4135/9781446213803.n11]

[23] Schmitt-Rodermund E. Pathways to successful entrepreneurship: Parenting, personality, early entrepreneurial competence, and interests. J Vocat Behav 2004; 65(3): 498-518.

[http://dx.doi.org/10.1016/j.jvb.2003.10.007]
[24] Phares EJ. Internal-external control as a determinant of amount of social influence exerted. J Pers Soc Psychol 1965; 2(5): 642-7. [http://dx.doi.org/10.1037/h0022710] [PMID: 5838762]

[25] Ginzberg E, Ginsburg SW, Axelrad S, Herma JL. Occupational Choice An Approach to a General Theory. Columbia University Press, Oxford University Press 1951.

[26] SOEP Group. SOEP-Core - 2018: Youth (16-17-year-olds, PAPI, with Reference to Variables) SOEP Survey Papers 807: Series A - Survey Instruments (Erhebungsinstrumente). DIW Berlin/SOEP 2020.

[27] Gosling SD, Rentfrow PJ, Swann WB. A very brief measure of the big-five personality domains. J Res Pers 2003; 37(6): 504-28.

[http://dx.doi.org/10.1016/S0092-6566(03)00046-1]

[28] John OP, Donahue EM, Kentle RL. The - Versions 4a and 54. Berkeley: University of California: Institute of Personality and Social Research 1991

[29] Gerlitz JY, Schupp J. Zur Erhebung der Big-Five-basierten Persönlichkeitsmerkmale im SOEP (The measurement of the Big Five personality traits in the SOEP). DIW Berlin/SOEP 2005.

[30] Lang FR, John D, Lüdtke O, Schupp J, Wagner GG. Short assessment of the Big Five: Robust across survey methods except telephone interviewing. Behav Res Methods 2011; 43(2): 548-67. [http://dx.doi.org/10.3758/s13428-011-0066-z] [PMID: 21424189]

[31] Nolte H, Weischer C, Wilkesmann U, Maetzel J, Tegethoff HG. Kontrolleinstellungen zum Leben und zur Zukunft Auswertung eines neuen, sozialpsychologischen Itemblocks im Soziooekonomischen Panel. Ruhr-Universität Bochum: Diskussionspapiere aus der Fakultaet für Sozialwissenschaft. 1997.

[32] Specht J, Egloff B, Schmukle SC. Everything under control? The effects of age, gender, and education on trajectories of perceived control in a nationally representative German sample. Dev Psychol 2013; 49(2): 353-64

[http://dx.doi.org/10.1037/a0028243] [PMID: 22545833]

[33] Ursachi G, Horodnic JA, Zait A. How reliable are measurement scales? External factors with indirect influence on reliability estimators. Procedia Econ Finance 2015; (20): 679-86. [http://dx.doi.org/10.1016/S2212-5671(15)00123-9]

[34] Hosmer DW, Lemeshow S. Goodness of fit tests for the multiple logistic regression model. Commun Stat Theory Methods 1980; 9(10): 1043-69. [http://dx.doi.org/10.1080/03610928008827941]

[35] Antoncic B, Kregar TB, Singh G, DeNoble AF. The Big Five personality-entrepreneurship relationship: Evidence from Slovenia. J Small Bus Manag 2015; 3(53): 819-41.

[http://dx.doi.org/10.1111/jsbm.12089]

[36] Hachana R, Berraies S, Ftiti Z. Identifying personality traits associated with entrepreneurial success: Does gender matter? Journal of Innovation. Economics and Management 2018; 27: 169-93.

[37] Kerr SP, Kerr WR, Xu T. Personality traits of entrepreneurs: A review of recent literature. FNT in Entrepreneurship 2018; 14(3): 279-356. [http://dx.doi.org/10.1561/0300000080]

[38] Kuhl J. Motivation und Persönlichkeit Interaktionen psychischer Systeme. Göttingen, Bern, Toronto, Seattle: Hogrefe 2001.

This is an open access article distributed under the terms of the Creative Commons Attribution 4.0 International Public License (CC-BY 4.0), a copy of which is available at: https://creativecommons.org/licenses/by/4.0/legalcode. This license permits unrestricted use, distribution, and reproduction in any medium, provided the original author and source are credited. 